\title{
Characterization of the Beekeeping Value Chain: Challenges, Perceptions, Limitations, and Opportunities for Beekeepers in Kayonza District, Rwanda
}

\author{
Borden Mushonga, ${ }^{1}$ Landouard Hategekimana, ${ }^{2}$ Gervais Habarugira ${ }^{(D)}{ }^{2}$ Erick Kandiwa, ${ }^{1}$ \\ Alaster Samkange $\mathbb{D}^{1},{ }^{1}$ and Basiamisi Victor Ernest Segwagwe ${ }^{3}$ \\ ${ }^{1}$ Department of Biomedical Sciences, School of Veterinary Medicine, Faculty of Agriculture and Natural Resources, \\ University of Namibia, P. Bag 13301, Pioneers Park, Windhoek, Namibia \\ ${ }^{2}$ School of Animal Sciences and Veterinary Medicine, University of Rwanda, PO Box 57 Nyagatare, Rwanda \\ ${ }^{3}$ Department of Biomedical Sciences, Faculty of Medicine, University of Botswana, P. Bag UB0074, Gaborone, Botswana
}

Correspondence should be addressed to Alaster Samkange; alastersamkange@gmail.com

Received 16 November 2018; Revised 26 March 2019; Accepted 18 April 2019; Published 22 May 2019

Academic Editor: Christos Tsadilas

Copyright (C) 2019 Borden Mushonga et al. This is an open access article distributed under the Creative Commons Attribution License, which permits unrestricted use, distribution, and reproduction in any medium, provided the original work is properly cited.

A survey was undertaken to characterize the honey production value chain and identify the challenges, limitations, and opportunities for beekeepers in Kayonza District, Eastern Rwanda, in light of the stagnation of the apiculture industry. The majority $(86 \%, n=100)$ of the beekeepers were adult males. Most of the respondents $(71 \%)$ lacked primary level education. The majority of the hives were made from hollow tree logs (40\%), tree barks (12\%), banana leaves/bark (11\%), cow dung (8\%), mud (7\%), grass (6\%), tree leaves (6\%), and the rest (20\%) were improved beehives, particularly Langstroth hives. The hive pests encountered were hive beetles (25\%), small black ants (19\%), wax moths (12\%), lizards ( $8 \%)$, termites (7\%), birds (6\%), mites (3\%), and mice (2\%). Fifty-five percent of the respondents hung their hives on trees to prevent pest invasion with $95 \%$ effectiveness, $25 \%$ frequently smoked their hives with $85 \%$ effectiveness, $16 \%$ cleared the bushes around apiaries with $55 \%$ effectiveness, and $4 \%$ used traditional plant insect repellents with $35 \%$ effectiveness. Forty-one percent of the respondents lacked adequate information on beekeeping, $25 \%$ had inadequate time to work on apiaries, $24 \%$ had inadequate technical knowledge and implements, and $10 \%$ needed additional labour for managing apiaries. Based on the results of this study, beekeeping in Kayonza is still largely traditional, characterized by the use of antiquated production methods and underutilization of available marketing channels. Perceptions in the district are that beekeeping is for the poor and illiterate. Challenges and limitations of beekeeping in Kayonza District include lack of education, gender bias, pests and diseases, absconding and swarming of bees, high costs, and lack of modern apicultural equipment. However, the potential for developing beekeeping enterprise (opportunities) is immense given the abundance of wild bee populations, possibility of women participation, abundance of honey collection centres (market), and availability of technical support from Government and development agencies. In conclusion, this study advocates the need for intervention measures to educate and promote production and marketing of quality honey, tackle pest and disease for beekeepers and boost Rwanda's apiculture industry.

\section{Introduction}

Kayonza District of Eastern Rwanda covers $1.937 \mathrm{~km}^{2}$ and is home to 80517 households with a population density of 178 people $/ \mathrm{km}^{2}$. This makes land the scarcest resource since $79 \%$ of this population depends on agriculture as a means of livelihood [1]. Kayonza District (1 $1^{\circ} 51^{\prime} \mathrm{S}, 30^{\circ} 39^{\prime} \mathrm{E}$ ) has an altitude between 1400 and $1600 \mathrm{~m}$. The district has a tropical climate with an average temperature of $19.7^{\circ} \mathrm{C}$, a variation of $+/-1.1^{\circ} \mathrm{C}$, and a total annual rainfall of 898 $\mathrm{mm}$ [2]. The vegetation comprises of forest savannah, the majority of which are flowering plants [3]. Half of Akagera National Park which is teeming with various flora and fauna is located in Kayonza District, rendering the district ideal for beekeeping. Consequently, a number of farmers in this district are engaged in subsistence beekeeping and this 
vocation offers much promise as a vehicle for sustainable rural development for the district.

The government of Rwanda has identified apiculture as a potential source of income to supplement crop and livestock farming for Rwandan farmers. Development agencies such as Rwanda Animal Resources Development Authority (RARDA), Centre for Support to Small and Medium Enterprises in Rwanda (CAPMER), Rwanda Association for Integrated Development (ARDI), and Netherlands Development Organization (SNV) are involved in supporting the beekeeping activities of farmers throughout Rwanda as strategic partners of the government. Though beekeeping has been passed down from generation to generation for many years, the first modern hive in Rwanda was introduced by Bauduin in 1966.

Bees are insects belonging to the order Hymenoptera, family Apidae, and genus Apis [4, 5]. The African honey bee, Apis mellifera scutellata, is the most important species for beekeeping in East and sub-Saharan Africa [6]. It has been observed that the global demand for honey and honey bee products is increasing on the back of a dwindling honeybee population due to massive "die-off" of bee colonies (colony collapse disorder) [7] spurned by environmentally unfriendly modern agricultural practices such as the use of pesticides and other factors such as habitat loss, pest invasion, pollution, overharvesting and disease $[7,8]$, and destruction of nesting sites [9].

Beekeeping is an integral component of agriculture, rural development, and national economic development and plays a critical role in conservation of ecosystems over the world [10-12]. Bees are a barometer of the health of natural ecosystems, pollinators of forests, horticultural and agricultural crops [13], and they are also kept for their marketable products. Such products include honey, which is used for both food and medicinal purposes [14, 15], wax, propolis, royal jelly, and pollen $[16,17]$. In Wisconsin, it has been demonstrated that beekeeping has the capacity of improving crop yields many times over for cranberry farmers [18]. In addition, farmers in the interface zones between game parks and human settlements have been reported to "fence" around the perimeters of their fields and homesteads with apiaries to ward off wild elephants [19]. Furthermore, beekeeping has been reported to have great ergonomic value in the occupational therapy of chronic back sufferers [10].

Honey production in Kayonza is largely subsistent. Honey produced is used as a supplementary food product, for medicinal purposes and for brewing traditional liquor [20]. Rwanda imported 1614 metric tonnes of honey to fulfill the 1715 metric tonne national demand due to the very limited production by 83,000 beekeepers owning a total of 93,000 beehives countrywide. The country is accredited to export honey to the European Union [21] and nearly 4000 tonnes of honey produced in 2015 was not enough to meet demand [22], meaning that market availability is not a constraint.

In spite of the strategic nature of beekeeping in terms of its potential to drive rural development, favourable agroecological conditions, the minimal cost for training and starting up, and sufficient availability of flowering plants, beekeeping is still regarded as a vocation for the illiterate and extremely poor people in Rwanda. This state of affairs has seriously curtailed beekeeping projects in Kayonza District.

Despite the multiplicity of development agencies and the millions of Rwandan francs poured into apiculture in Rwanda, there is a paucity of published information on the current status of beekeeping and characteristics of the beekeeping value chain in Rwanda, and Kayonza District, in particular. The aims of this study were to highlight the potential of beekeeping as an alternative to crop and to animal production and investigate the features of the beekeeping value chain: its challenges, limitations, and opportunities for the beekeepers of Kayonza District. The study also aims to document and evaluate the efficacy of the various measures local beekeepers have resorted to in a bid to deal with challenges of the beekeeping value chain. It is hoped that information gathered would help formulate recommendations on further research essential for the survival of apiculture and improvement of honey production in Rwanda.

\section{Methodology}

2.1. Study Area. The study was conducted in Kayonza District $\left(1^{\circ} 51^{\prime} S, 30^{\circ} 39^{\prime} \mathrm{E}\right)$ in the Eastern Province of the Republic of Rwanda. The district covers an average area of $1,937 \mathrm{~km}^{2}$, with a total human population of 343496 , at a density of 178 inhabitants $/ \mathrm{km}^{2}$ [23]. The study focused on seven of the 12 sectors. Inhabitants of these seven sectors live in an exclusively rural (98.6\%) lifestyle. The majority of the people survive as small-scale traders, subsistence pastoralists, and/or crop farmers. The total number of beekeepers in Kayonza District was about 2140 households [23].

2.2. Study Design and Data Collection. A cross-sectional questionnaire based survey was used to collect data. Purposive sampling was done targeting only beekeeping households. The households were divided into subpopulations (strata) using a simple stratified random sampling. A total of 100 beekeepers were used in the study from the $7 \mathrm{sec}-$ tors including Gahini, Mwiri, Murundi, Ndego, Rwinkwavu, Murama, and Kabare. Of these respondents, $86 \%$ were adult males (above 24 years of age), $6 \%$ were adult females (above 24 years of age), and the rest were youths (aged from 14 to 35 years) [23]. Primary data were collected from structured interviews and focused group discussions with key informants (trained and selected cooperative members to give and to collect information by distributing questionnaires) from beekeeper cooperatives. The secondary data were collected from past beekeeping records and from the current authors' inspection of hives and apiaries.

2.3. Data Analysis. The primary and secondary data collected from the respondents was entered into Microsoft Excel 2013 spreadsheets. Data frequencies, tables, and graphs were done using Microsoft Excel 2013. The Z test was used for comparison of proportions of respondents' categorical crosstabulations with $95 \%$ confidence interval [24]. 
2.4. Ethical Considerations. Ethical approval (by official confirmation notice) for this study was obtained from the Research Committee of the School of Animal Sciences and Veterinary Medicine, College of Agriculture Animal Sciences and Veterinary Medicine, University of Rwanda. Beekeepers were first informed about the purpose and procedures and provided written consent prior to study procedures. Data were collected in a strict confidential atmosphere between the interviewer and the beekeeper.

\section{Results}

Based on the respondents interviewed, as shown in Figure 1 and Table 1, the majority of the beekeepers (86\%) in Kayonza were significantly adult males $(\mathrm{p}<0.05)$. There was no significant difference in the involvement of adult females $(6 \%)$ and youths ( $8 \%)$ in beekeeping ( $\mathrm{p}>0.05)$.

As shown in Figure 2 and Table 1, 71\% of the respondents lacked basic primary level of education, with only $23 \%$ having attained primary level and a mere $6 \%$ having attained secondary level of education. None of the respondents had tertiary education.

As shown in Tables 2 and 3, a larger proportion of respondents used hives constructed out of hollow tree logs $(40 \%, p<0.001)$ than those using the other forms of hives. The proportion of respondents using Langstroth hives (20\%; $p<.05$ ) was only greater than those using cow dung, mud, grass, and tree leaves.

As shown in Tables 4 and 5, a greater proportion of respondents $(55 \%, p<.0001)$ preferred suspension of hives in trees as the method of prevention and control of pests than those preferring other forms of pest control. The least proportion of respondents $(4 \%, p<.01)$ preferred use of insect repellents of plant origin for pest control.

As shown in Tables 6 and 10, a greater proportion of respondents used beeswax $(40 \%, p<.05)$ than those using viper skin. There was, however, no difference in the proportion of respondents using beeswax and those using propolis or those using propolis and those using viper skin ( $p>05)$.

A greater proportion of respondents reported infestation of hives with beetles and small black ants $(25 \%$ and $19 \%$, respectively; $p<.05)$ than those reporting infestation with moths, lizards, termites, birds, mites, and mice (Tables 9 and 10). There was, however, no difference in the proportion of respondents reporting infestation of hives with termites, birds, mites, and mice.

A greater proportion of respondents used open fire to produce smoke than those that used modern smokers or torches ( $80 \%$ and $20 \%$, respectively; $p<.0001$ ) for harvesting honey from beehives.

A greater proportion of respondents cited a lack of sufficient information on individual pests, predators, and diseases of honeybees $(34 \%, p<.01)$ as a constraint in beekeeping than those that cited the lack of adequate time for the management of colonies, flying predators, nocturnal predators and pests, lack of adequate technical knowledge and implements for the management and control of predators, pests, and honeybee diseases, and lack of sufficient labour (Tables 8 and 10).

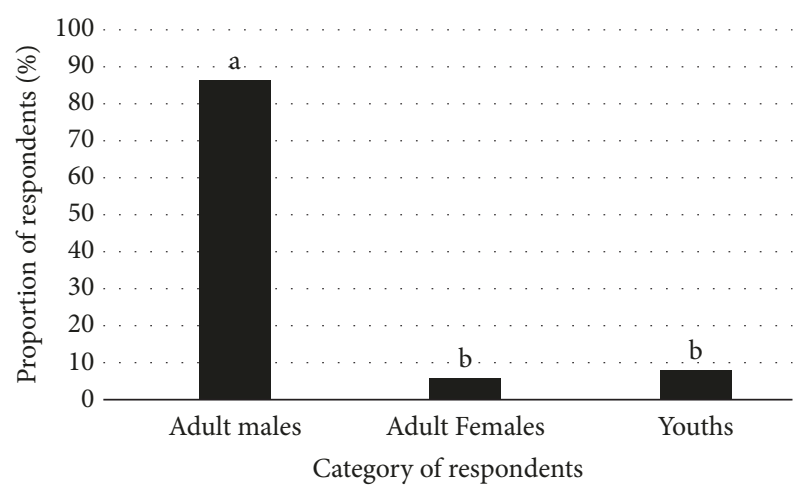

Figure 1: Proportional distribution of beekeepers in Kayonza District, Rwanda. ${ }^{\text {a,b }}$ Values with different suffices were significantly different since $p<.05$.

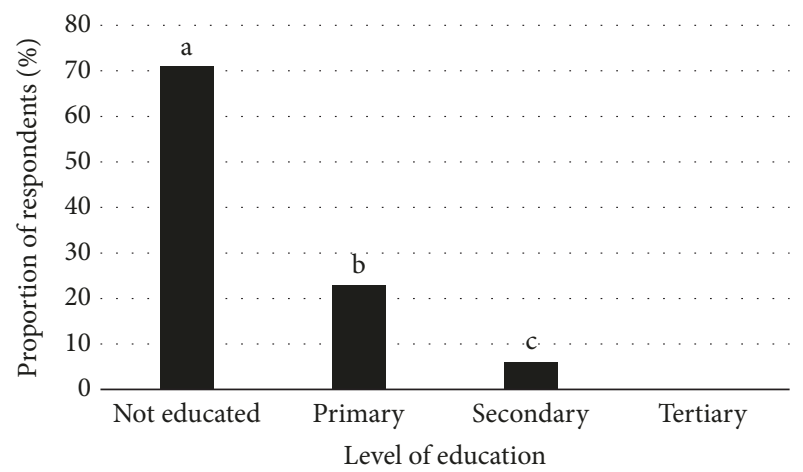

Figure 2: Proportional level of education of beekeepers in Kayonza. ${ }^{a, b, c}$ Values with different suffices were significantly different since $p<.001$.

The proportion of respondents claiming that bees abandoning colonies was a result of pests and diseases in colonies was greater $(45 \%$; $p<.0001)$ than that claiming that increased migration of colonies, high mortality of adult bees and brood, increased aggressiveness, and increased swarming behaviour of bees were the results of pests and diseases on bee colonies (Tables 7 and 10).

\section{Discussion}

The majority ( $86 \%$ ) of the respondents were adult males compared to $6 \%$ adult females and $8 \%$ male and female youths combined (Figure 1 and Table 1). Our results showing male dominance of the beekeeping vocation are in agreement with several other studies on the African continent and beyond with percentages ranging from 68 to $95 \%$ across the border in Uganda [13, 19], around $82-100 \%[16,25,26]$ in Ethiopia, to as high as $100 \%$ in the Federal Capital territory, Abuja, Nigeria [12]. However, the high representation of males in the beekeeping vocation goes against the grain of the general perception that the majority of rural farmers are women and the fact that there are more women (52\%) than men (48\%) in Rwanda [27]. It would appear that a scenario of male domination in this vocation arises from the fact that 
TABLE 1: P-value matrix for cross tabulation of sex, age group, and educational level categories of respondents.

\begin{tabular}{|c|c|c|c|}
\hline \multicolumn{4}{|c|}{ Age categories } \\
\hline & Adult males & Adult females & Youths \\
\hline Adult males & - & .00001 & .00001 \\
\hline Adult females & - & - & .58232 \\
\hline Youths & - & - & - \\
\hline \multicolumn{4}{|c|}{ Educational level categories } \\
\hline & None & Primary & Secondary \\
\hline None & - & .00001 & .00001 \\
\hline Primary & - & - & .00064 \\
\hline Secondary & - & - & - \\
\hline
\end{tabular}

TABLE 2: P-value matrix for cross tabulation of proportional use of hive-fashioning materials by respondents.

\begin{tabular}{|c|c|c|c|c|c|c|c|c|}
\hline \multicolumn{9}{|c|}{ Type of hive and fashioning materials } \\
\hline & Tree logs & Tree barks & Banana & Cow dung & Mud & Grass & Tree leaves & Langstroth \\
\hline Tree logs & - & .00001 & .00001 & .00001 & .00001 & .00001 & .00001 & .002 \\
\hline Tree-bark & - & - & .82588 & .34722 & .22628 & .13888 & .13888 & .12356 \\
\hline Banana & - & - & - & .47152 & .32218 & .20408 & .20408 & .0784 \\
\hline Cow dung & - & - & - & - & .78716 & .58232 & .58232 & .01428 \\
\hline Mud & - & - & - & - & - & .77182 & .77182 & .00714 \\
\hline Grass & - & - & - & - & - & - & 1 & .00328 \\
\hline Tree leaves & - & - & - & - & - & - & - & .00328 \\
\hline
\end{tabular}

TABLE 3: Proportions of the types of hives used by beekeepers in Kayonza.

\begin{tabular}{|c|c|c|}
\hline Type of Hive & Material used for fashioning hives & Number of respondents (\%) \\
\hline \multirow[t]{7}{*}{ Traditional } & Hollow tree logs & $40(40)^{\mathrm{a}}$ \\
\hline & Tree bark & $12(12)^{b c}$ \\
\hline & Banana leaves and bark & $11(11)^{b c}$ \\
\hline & Cow dung & $8(8)^{\mathrm{b}}$ \\
\hline & Mud & $7(7)^{b}$ \\
\hline & Grass & $6(6)^{\mathrm{b}}$ \\
\hline & Tree leaves & $6(6)^{\mathrm{b}}$ \\
\hline Modern (Langstroth hives) & Wood or plastic and wax & $20(20)^{\mathrm{c}}$ \\
\hline Total & & $100(100)$ \\
\hline
\end{tabular}

TABLE 4: P-value matrix for cross tabulation of respondents' preferred method of prevention and control of bee hive pests.

\begin{tabular}{lcccc}
\hline & \multicolumn{3}{c}{ Method of prevention and control of bee hive pests } \\
\hline & \multicolumn{1}{c}{ Suspension of hives } & Frequent smoking of hives & Clearing around apiaries & Insect repellants of plant origin \\
\hline Suspension of hives & - & 0.00001 & 0.00001 & 0.00001 \\
Frequent smoking of hives & - & - & 0.1141 & 0.00001 \\
Clearing around apiaries & - & - & - & 0.00466 \\
Insect repellants of plant origin & - & - & - & - \\
\hline
\end{tabular}

TABLE 5: Respondents' methods of choice for pest control and prevention and their perceived effectiveness.

\begin{tabular}{lr}
\hline Respondents' method for prevention and control of pests & Number of respondents (\%) \\
\hline Suspension or hanging of hives in trees & $55(55)^{\mathrm{a}}$ \\
Frequent smoking of hives & $25(25)^{\mathrm{b}}$ \\
Bush clearing around apiaries & $16(26)^{\mathrm{b}}$ \\
Insect repellents of plant origin & $4(4)^{\mathrm{c}}$ \\
\hline Total & $100(100)$ \\
\hline $\mathrm{a}, \mathrm{b}, \mathrm{c}$
\end{tabular}

$\overline{\mathrm{a}, \mathrm{b}, \mathrm{c}}$ Values with different suffixes were significantly different since $p<0.01$. 
TABLE 6: P-value matrix for cross tabulation of method of bee baiting.

\begin{tabular}{lccc}
\hline & \multicolumn{3}{c}{ Method of bee baiting } \\
\hline & Beeswax & Propolis & Viper skin \\
\hline Beeswax & - & .37886 & .03486 \\
Propolis & - & - & .2187 \\
Viper skin & - & - & - \\
\hline
\end{tabular}

males brave the stings of bees and are able to make their own hives, thereby reducing startup and operational costs. Such a scenario does not bode well for the future prospects of viability and sustainability of the beekeeping industry in Rwanda, given that women constitute more than $52 \%$ of the population.

Results from this study (Figure 1 and Table 1) showed that $71 \%$ of the respondents did not attain basic primary level of education, with only $23 \%$ having attained primary level and a mere $6 \%$ with secondary level of education (Figure 2 and Table 1). None of the respondents had attained tertiary education. In stark contrast to our findings, Akinmulewo and coworkers reported that $63 \%$ of the beekeepers had secondary education in Abuja, Nigeria [12], and Mujuni and others reported $42.5 \%$ and $17.3 \%$ of the beekeepers having attained secondary and tertiary levels of education, respectively [13]. The relative lack of formally educated people involved in apiculture does not bode well for the future prospects of the subsector. It is possibly a result of myth and the general perception by the locals of Kayonza that beekeeping is not of economic importance and is thus reserved for people with no tangible assets, livestock, or land and those being in dire need of employment. It seemed that those involved in beekeeping were doing so as a hobby. Proper and targeted education through veterinary extension services would be needed for the locals to appreciate the commercial potential of apiculture and the resultant environmental benefits through preservation of both flora and fauna.

Most $(80 \%)$ of the hives encountered in this study were of the traditional type fashioned from hollow tree logs, tree bark, cow dung, mud, grass, and banana tree leaves and only 20\% were Langstroth hives (Tables 2 and 3). Thus the production system was largely traditional and modern. Berhe and coworkers identified a "third way" (production system) that is called the transitional system [16].

Our results are in agreement with the results of other workers $[19,25]$ who reported $79.1 \%$ and $67.3 \%$ usage of traditional hives in Ethiopia and Uganda, respectively. However, the results from this study contradict the findings of Gebremeskel and coworkers, who reported higher usage of modern hives than traditional hives in Eastern Ethiopia [28]. It has previously been suggested that hive type is one of the factors influencing beekeeping and honey production $[11,29]$.

According to some authors $[16,30]$, adoption of modern beekeeping technology hives can produce more honey leading to improved standards of living of the beekeepers [31]. In fact, Gebiso demonstrated an average productivity of $19.77 \mathrm{~kg} / \mathrm{hive}$ with modern hives and $5.13 \mathrm{~kg} / \mathrm{hive}$ with traditional hives [25]. Furthermore, Gebiso argued that, by just encouraging the adoption of modern hive usage by $50 \%$, the industry stood to increase total production by doubling the honey produced by local hive beekeepers [25]. Perhaps, this is the best intervention for beekeepers of Kayonza District. Furthermore, it has already been demonstrated that baited wooden hives attract bee pests even before they attract the bees [32]. The biggest challenge with traditional hives is the fact that they are made from materials that normally make up the habitats of honeybee pests such as hive beetles (Aethina spp.), wax moth (Acroia and Galleria spp.), little black ants (Monomorium minimum), and red ants (Solenopsis spp.). It is unfortunate that the transitional production system which serves as a springboard into modern beekeeping was not identified in the study. Effort must be put into encouraging beekeepers to transition into this phase and then further metamorphose into modern beekeeping.

The beekeepers used various methods (viper skin, beeswax, and propolis) to bait wild bees in order to facilitate capture of swarms for setting up apiaries (Table 5). They, however, lacked the adequate capacity of effectively setting up and managing apiaries towards increasing the quantity and quality of production to levels achieved elsewhere in the region [33]. Knowledge on how to bait bees into hives was limited for most farmers.

The most frequently encountered pests as noted by the beekeepers were hive beetles (Aethina spp.), followed by wax moths (Acroia and Galleria spp.), red ants (Solenopsis spp.), little black ants (Monomorium minimum), mites (Varroa destructor), lizards, and birds. Rats were reported as rare pests. The information gained on the proportional occurrence of pests and predators from the field by the authors through inspection of 100 hives and apiaries was nearly similar to the information presented by the beekeepers. The hive beetles (adults and larvae) feed on pollen, honey, and the drone brood which has devastating effects on the growth of bee colonies. Honey harvested from infested hives tends to have an undesirable and unmarketable smell and ferments upon storage.

Other than beetles, small black ants (Monomorium minimum) were one of the most important honeybee pests causing economic losses for beekeepers in Kayonza. They suck out the honey and kill the pupae and eggs. They are too small to be stopped by hive guard bees and in many cases they resulted in bees abandoning their hives. Similar observations were reported by Kistner in South Africa, who concluded that ants were serious pests of honeybees and that their persistent attacks induced colonies to abandon their hives [34]. Red ants (Formica spp.) were as equally threatening as small black ants. Red ants feed on honey and brood causing the colony to weaken and migrate. Similar findings were recorded in Nepal [35]. However some of the pests (wasps, skunks, and honey badgers) were not encountered in Kayonza, possibly due to the high human population density in the district.

Results from this study showed that wax moths (Galleria spp.) constituted $18 \%$ of the pests recorded in the study. This result was lower than the $27.4 \%$ reported in Ethiopia [36]. It is known that larvae of the wax moth (Galleria spp.) 
TABLE 7: P-value matrix for cross tabulation of perceived effect of pests and diseases.

\begin{tabular}{lcccc}
\hline & \multicolumn{4}{c}{ Perceived effect of pests and diseases on colonies } \\
\hline & Migration of colonies & Weakened colonies & Increased aggression & Frequent swarming \\
\hline Migration of colonies & - & .00001 & .00001 & .00001 \\
Weakened colonies & - & - & .00262 & .00016 \\
Increased aggression & - & - & - & .35238 \\
Frequent swarming & - & - & - & - \\
\hline
\end{tabular}

TABLE 8: P-value matrix for cross tabulation of challenges faced by respondents.

\begin{tabular}{|c|c|c|c|c|c|c|}
\hline & \multicolumn{6}{|c|}{ Challenges faced by respondents } \\
\hline & Lack of information & Inadequate time & Flying predators & Nocturnal predators & Lack of technology & Inadequate labour \\
\hline Lack of information & - & .00578 & .0018 & .00046 & .0001 & .00001 \\
\hline Inadequate time & - & - & .69654 & .42952 & .22246 & .14706 \\
\hline Flying predators & - & - & - & .6818 & .4009 & .28462 \\
\hline Nocturnal predators & - & - & - & - & .65994 & .50926 \\
\hline Lack of technology & - & - & - & - & - & .8181 \\
\hline Inadequate labour & - & - & - & - & - & - \\
\hline
\end{tabular}

feed on the comb and sometimes the woodenware of the hives [37-39]. Infestation of hives with these larvae results in destruction of combs leading to bee colony weakening and eventual migration [40]. In addition to the moths, lizards (Trachylepis striata) were sporadically sighted in the proximity of hives or living between the lids and the main bodies of the hives and feeding on adult worker bees crawling outside the hives. Regular routine inspection of hives for parasite identification is recommended for the beekeepers of Kayonza.

Previous research has reported that the European beeeater (Merops apiaster Linnaeus 1758) is highly migratory and is found in tropical Africa [41-43]. The bird feeds on various insects but bees make up to $82 \%$ of its diet [43]. They catch the worker bees in flight and can eat up to 250 bees a day, although they can only deplete the worker bee population by $1 \%$ [44]. This predator therefore is not considered a serious threat to apiculture.

Though visible to the naked eye, mites (Varroa destructor) were only known to a few elderly beekeepers. Microscopy is greatly beneficial in diagnosis of mite infestation. Mites feed on the bodily fluids of adult, pupal, and larval bees leading to their death and decomposition. Mites are also vectors of a particularly damaging virus (deformed wing virus) which has reportedly led to virtual elimination of feral bee colonies [45]. These mites have been closely associated with the colony collapse disorder in apiaries and have been pointed out as the most serious threat to colony health by several studies [46, 47]. Provision of chemicals such as amitraz to farmers has been reported to be effective in the control of this parasite. Perhaps the government may help in this regard.

Mice (Mus spp.) nests were found in corners away from the bee clusters within some hives. Mice in hives destroy combs during late summer and winter months. Mouse urine has a repulsive odour and cannot be cleaned out by the bees in the spring resulting in adulterated honey at harvest. Mouse invasion of beehives was mostly experienced in apiaries located near woodlots or in banana tree groves. Termites feed on the woodenware of hives and thus termite infestation of hives resulted mainly in gradual destruction of hives leaving apertures and openings that would allow other pests to access the hives.

The beekeepers relied on sighting of pests and predators during inspection of hives as evidence of the presence of honey bee pests. In addition, empty hives at the time of harvest time was considered as evidence of abandoning bees. Decrease in the size of bee colonies, abundance of bees staying outside the hives, and unstable flights (frequent in and out flights) were the other indicators used by the respondents as evidence of bee disease or pest infestation.

The study also showed that $80 \%$ of the beekeepers used open fires for smoke production during the honey harvests while only $20 \%$ relied on modern smokers or torches. The majority of beekeepers in Kayonza District used grass, on top of which they would put wet leaves to produce smoke. The smoke imparts an undesirable odour to the honey while the ash from the grass would fall on the honey, thereby contaminating it and rendering it of lower commercial value. According to Suresh Kumar and coworkers the aim of every beekeeping enterprise is to harvest pure uncontaminated honey [48]. In addition, the use of fires may increase the risk of accidental veld fires especially during dry months. It is therefore imperative that modern methods of apiculture be fostered on the people of Kayonza.

Other less accurate methods included evidence of bees invading people's homes. The study showed that $55 \%$ of the respondents perceived the presence of high numbers of dead bees in and around hives as evidence of disease presence. Some respondents used reduced flight activity (22\%), reduced comb construction (13\%), and presence of moulds (10\%) as evidence of presence of bee disease(s). The present survey revealed that beekeepers in Kayonza relied mostly on hive and environmental inspection for diagnosis of honey bee 
TABLE 9: P-value matrix for cross tabulation of types of predators/pests.

\begin{tabular}{lccccccccc}
\hline & \multicolumn{1}{c}{ Types of predators and pests } \\
\hline & Beetles & Black ants & Red ants & Moths & Lizards & Termites & Birds & Mites & Mice \\
\hline Beetles & - & .3077 & .23014 & .01778 & .0012 & .00052 & .0002 & .00001 & .00001 \\
Black ants & - & - & .85716 & .17068 & .0226 & .01174 & .00544 & .0003 & .00008 \\
Red ants & - & - & - & .23404 & .03572 & .01878. & .00906 & .00054 & .00016 \\
Moths & - & - & - & - & .34722 & .22628 & .13888 & .01552 & .0056 \\
Lizards & - & - & - & - & - & .78716. & .58232 & .12114 & .05118 \\
Termites & - & - & - & - & - & - & .77182 & .1936 & .08726 \\
Birds & - & - & - & - & - & - & - & .30772 \\
Mites & - & - & - & - & - & - & -14986 \\
Mice & - & - & - & - & - & - & - & - & .65272 \\
\hline
\end{tabular}

TABLE 10: Proportional occurrence of various aspects experienced and practised by respondents.

\begin{tabular}{|c|c|}
\hline Aspect investigated & Number of respondents (\%) \\
\hline \multicolumn{2}{|l|}{ Method of Baiting } \\
\hline Beeswax & $40(40)^{\mathrm{a}}$ \\
\hline Propolis & $34(34)^{\mathrm{a}, \mathrm{b}}$ \\
\hline Viper skin & $26(26)^{b}$ \\
\hline \multicolumn{2}{|l|}{ Type of pest/predator } \\
\hline Beetles (Aethina tumida) & $25(25)^{\mathrm{a}}$ \\
\hline Small black ants (Monomorium minimum) & $19(19)^{\mathrm{a}}$ \\
\hline Red ants (Formica spp.) & $18(18)^{\mathrm{b}}$ \\
\hline Wax moths (Galleria spp.) & $12(12)^{\mathrm{b}}$ \\
\hline Lizards (Trachylepis striata) & $8(8)^{c, d}$ \\
\hline Termites & $7(7)^{c, d}$ \\
\hline Birds (Merops apiaster) & $6(6)^{\mathrm{c,d}}$ \\
\hline Mites (Varroa destructor) & $3(3)^{\mathrm{d}}$ \\
\hline Mice (Mus spp.) & $2(2)^{\mathrm{d}}$ \\
\hline \multicolumn{2}{|l|}{ Respondents' method of harvesting honey } \\
\hline Open fire to produce smoke & $80(80)^{\mathrm{a}}$ \\
\hline Modern smokers or torch & $20(20)^{\mathrm{b}}$ \\
\hline \multicolumn{2}{|l|}{ Type of challenge faced by respondents } \\
\hline Lack of information on pests and predators of honeybees & $34(34)^{\mathrm{a}}$ \\
\hline Inadequate time for management of colonies & $17(17)^{\mathrm{b}}$ \\
\hline Flying predators (e.g., birds) & $15\left(15^{\mathrm{b}}\right.$ \\
\hline Nocturnal predators and pests & $13(13)^{\mathrm{b}}$ \\
\hline Inadequate technical knowledge and implements & $11\left(11^{\mathrm{b}}\right.$ \\
\hline Inadequate labour & $10(10)^{\mathrm{b}}$ \\
\hline \multicolumn{2}{|l|}{ Perceived effect of pests and diseases on colonies } \\
\hline Bees abandoned hives and migrated & $67(67)^{\mathrm{a}}$ \\
\hline Brood and adult bees died leaving weaker colonies & $22(22)^{b}$ \\
\hline Bees became more aggressive & $7(7)^{\mathrm{c}}$ \\
\hline Bees swarmed frequently & $4(4)^{\mathrm{c}}$ \\
\hline
\end{tabular}

$\overline{\mathrm{a}, \mathrm{b}, \mathrm{c}, \mathrm{d}}$ Values with the same suffices within each category are significantly different since $p<0.05$.

pests and diseases. The more elderly beekeepers showed more experience and understanding in the interpretation of the findings of these inspections. However, there was a common misconception that moulds indicated cold instead of chalkbrood as the primary problem [49-51]. This showed that inspection alone was not sufficient in disease diagnosis.
Therefore, there is a need to educate beekeepers on the merits of sample collection and microscopic examination in the diagnosis of the most honeybee diseases. This education would also need to be supported by provision of implements and laboratory services for complete diagnostics on the samples submitted by the beekeepers. 


\section{Conclusions}

This study provided information on the current status of apiculture in Kayonza District by exposing an array of challenges to apiculture in the district and possibly the country at large. Despite the obvious proof of organisations having initiated beekeeping projects and set up marketing centres, there has been very poor veterinary extension involvement in the continued education and support of the budding beekeepers. Since $80 \%$ of the hives encountered in the survey were of the traditional type and only $6 \%$ of the beekeepers were adult females, it is imperative that the whole beekeeping operation should be reorganised by first educating and training on modern hive construction, bee catching techniques, apiary management and maintenance, disease and pest diagnosis, and intervention target groups (women, illiterate, unemployed, and poor persons) and then by financially equipping them through organisations that have been devoted to the development of apiculture in Rwanda. Local authorities should promote the establishment of beekeeper associations that can facilitate effective communication between donor organisations and the budding beekeepers. Further realignment of government policies to assist the progress and welfare of beekeeper associations is bound to give excellent results as it has in neighbouring countries.

\section{Data Availability}

The data used to support the findings of this study are available from the corresponding author upon request.

\section{Disclosure}

The authors declare that they have no financial or personal relationships which may have inappropriately influenced them in writing this article.

\section{Conflicts of Interest}

The authors declare that they have no conflicts of interest.

\section{Authors' Contributions}

Borden Mushonga (University of Namibia) contributed to the project design and coordination, manuscript writing, and editing. Landouard Hategekimana (University of Rwanda) contributed to data collection and writing of the manuscript. Gervais Habarugira (University of Rwanda) contributed to the write-up and editing of the manuscript. Erick Kandiwa (University of Namibia) contributed to manuscript writing and editing. Alaster Samkange (University of Namibia) contributed to manuscript writing and editing. Basiamisi Victor Ernest Segwagwe (University of Botswana) contributed to manuscript writing and editing.

\section{Acknowledgments}

The authors are thankful to the authorities of Kayonza District to have authorised to carry out this study. We also express our sincere appreciation to beekeepers and their cooperatives. Many thanks are due to College of Agriculture and Animal Science of the University of Rwanda for funding the research and the University of Namibia and University of Botswana for funding the publication of this manuscript.

\section{References}

[1] S. N. V. East and S. Africa, Window of Opportunity: Income from Honey, 2008.

[2] Anon, Climate Kayonza, 2019, https://en.climate-data.org/ africa/rwanda/east-province/kayonza-28968/, [Accessed: 24Mar-2019].

[3] Anon, Kayonza District Development Plan, 2009.

[4] C. Malloy, Honeybees: Foraging Behaviour, Reproductive Biology and Diseases, Nova Science Publishers, New York, NY, USA, 2014.

[5] H. R. Hepburn, C. W. W. Pirk, and O. Duangphakdee, "Honeybee nests: Composition, structure, function," Honeybee Nests: Composition, Structure, Function, vol. 9783642543289, pp. 1389, 2014.

[6] S. K. Raina, E. Kioko, O. Zethner, and S. Wren, "Forest habitat conservation in africa using commercially important insects," Annual Review of Entomology, vol. 56, pp. 465-485, 2011.

[7] K. Ball and M. Haynes, "Introducing the "Global Animal": An Insomniac's Recourse in the Anthropocene," ESC: English Studies in Canada, vol. 39, no. 1, pp. 1-26, 2013.

[8] P. A. S. Tette, F. A. Da Silva Oliveira, E. N. C. Pereira, G. Silva, M. B. De Abreu Glória, and C. Fernandes, "Multiclass method for pesticides quantification in honey by means of modified QuEChERS and UHPLC-MS/MS," Food Chemistry, vol. 211, pp. 130-139, 2016.

[9] K. Vijayakumar, M. Muthuraman, and K. R. Jayara, "Effect of modern agricultural intensification on cavity nesting honey bee (Apis cerana indica Fabricius) colonies," International Journal of Advanced Life Sciences, vol. 3, pp. 87-91, 2012.

[10] A. A. Aiyeloja, G. A. Adedeji, and E. A. Emerhi, "Impacts of beehive stands' heights and hives' types on the ergonomics of honey harvesting in Port Harcourt, Nigeria," New York Science Journal, vol. 8, no. 4, pp. 23-27, 2015.

[11] M. Alsharhi et al., "The priority of modern hives for beekeeping and honey production in Yemen," in Proceedings of the in 13th Asian Apicultural Associaion Conference, pp. 3-4, no, 2016.

[12] B. O. Akinmulewo, Y. U. Oladimeji, and Z. Abdulsalam, "Assessment of the profitability of improved apiculture in federal capital territory (FCT) abuja, nigeria," Journal of Sustainable Development in Africa, vol. 19, no. 2, pp. 24-37, 2017.

[13] A. Mujuni, K. Natukunda, and D. R. Kugonza, "Factors affecting the adoption of beekeeping and associated technologies in Bushenyi District, Western Uganda," Livestock Research for Rural Development, vol. 24, no. 8, 2012.

[14] S. Pathare, P. Ravikumar, and A. Mistry, "Promising pharmaceutical applications of honey: a review," World Journal of Pharmaceutical Sciences, vol. 4, no. 5, pp. 377-392, 2015.

[15] T. Eteraf-Oskouei and M. Najafi, "Traditional and modern uses of natural honey in human diseases: a review," Iranian Journal of Basic Medical Sciences, vol. 16, no. 6, pp. 731-742, 2013.

[16] A. Berhe, A. Asale, and D. Yewhalaw, "Community perception on beekeeping practices, management, and constraints in termaber and basona werena districts, central ethiopia," Advances in Agriculture, vol. 2016, Article ID 4106043, 9 pages, 2016. 
[17] N. L. Carreck, "Improving the quality and productivity of apitherapy products," in Proceedings of the 45th Apimondia Congress, vol. 12, 2017.

[18] H. R. Gaines-Day and C. Gratton, "Crop yield is correlated with honey bee hive density but not in high-woodland landscapes," Agriculture, Ecosystems \& Environment, vol. 218, pp. 53-57, 2016.

[19] E. K. Ndyomugyenyi, I. Odel, and B. Okeng, "Assessing honey production value chain in Lira Sub-county, Lira district, Northern Uganda," Livestock Research for Rural Development, vol. 27, no. 1, 2015.

[20] E. Mukarugwiza, “The hope for rural transformation: A rejuvenating cooperative movement in Rwanda," Dar es Salaam, vol. 12,2010

[21] RAB., Apiary Sub-Program, Kigali, Rwanda, 2015.

[22] E. Ntirenganya, Honey Shortage as EU Market Demands More, The New Times, Kigali, Rwanda, 2016.

[23] NISR, Population size, structure and distribution, Kigali, Rwanda, 2014.

[24] J. Stangroom, Social Science Statistics, 2018, http://www .socscistatistics.com/Default.aspx, [Accessed: 02-Nov-2017].

[25] T. Gebiso, "Adoption of modern bee hive in arsi zone of oromia region: determinants and financial benefits," Agricultural Sciences, vol. 6, pp. 382-296, 2015.

[26] S. Fikru and G. Gebresilassie, "Assessment of beekeeping practices (absconding, bee forage and bee diseases and pests) in jigjiga zone, somali regional state of ethiopia," Poultry, Fisheries \& Wildlife Sciences, vol. 03, no. 02, 2015.

[27] J. B. Gakumba, Final Project Report: Community Based Climate Change, 2015.

[28] Y. Gebremeskel, B. Tamir, and D. Begna, "Characterization of bee-keeping systems and honey marketing in Eastern zone Tigray, Ethiopia," Livestock Research for Rural Development, vol. 26, no. 10, 2014.

[29] H. U. Khan, S. I. Anjum, and N. Sultana, "Honey production potential of the honey bee (Apis mellifera) in Karak and Kohat," J. Entomol. Zool. Stud, vol. 4, no. 6, pp. 559-564, 2016.

[30] A. Abeje, K. Ayen, M. Awoke, and L. Abebaw, "Adoption and intensity of modern bee hive in Wag Himra and North Wollo zones, Amhara Region, Ethiopia," Agricultural and Resource Economics: International Scientific E-Journal, vol. 3, no. 1, pp. 526, 2017.

[31] R. K. Gupta, "Technological innovations and emerging issues in beekeeping," in Beekeeping for Poverty Alleviation and Sustainable Rural Livelihood, W. Reybroeck, J. W. van Veen, and A. Gupta, Eds., pp. 507-554, Springer, London, UK, Netherlands, 2014.

[32] J. Talairach and P. Thournoux, "Co-existence and interactions of pest with bee-wax baited Gmelina arborea ( Roxb .) woodhives in Abeokuta, Nigeria," Journal of Agriculture and Veterinary Sciences, vol. 8, no. 2, pp. 68-72, 2015.

[33] G. A. Adedeji and A. A. Aiyeloja, "Preference and Suitability of Nigerian Grown Gmelina arborea Linn. Roxb. and Vitex doniana Sweet Woods for Beekeeping in Imeko, Nigeria," International Journal of Scientific and Engineering Research, vol. 5, no. 5, pp. 1484-1493, 2014.

[34] D. H. Kistner, "Applied myrmecology: a world perspective," Annals of the Entomological Society of America, vol. 85, no. 1, pp. 103-104, 1992.

[35] K. R. Neupane, "Pests and predators of honey bee species of Nepal," in Proceedings of the 24th Apimondia International Apiculture Congress, 2015.
[36] E. Kebede, "Prevalence of wax moth in modern hive with colonies in kafta humera," Animal and Veterinary Sciences, vol. 3, no. 5, p. 132, 2015.

[37] E. Torcoli, I. Amoruso, E. Moretto, G. U. Caravello, and V. Giaccone, Small scale experimental insect farming?: compliance of raw insects and processed flour with food hygiene requirements, Wageningen, Netherlands, 2014.

[38] K. A. Hussein, M. A. A. Abdel-Rahman, A. Y. Abdel-Mallek, S. S. El-Maraghy, and J. H. Joo, "Pathogenicity of Beauveria bassiana and Metarhizium anisopliae against Galleria mellonella," Phytoparasitica, vol. 40, no. 2, pp. 117-126, 2012.

[39] M. A. A. El-Niweiri, Survey of the pests and diseases of honeybees in Sudan, University of Khartoum, 2004.

[40] N. Taredahalli, N. S. Bhat, A. R. V. Kumar, and M. S. Jakhar, "A biological approach for management of greater wax moth, Galleria mellonella L. using Bacillus thuringiensis," Journal of Biological Control, vol. 27, no. 4, pp. 329-333, 2013.

[41] N. Sapir, N. Horvitz, M. Wikelski, R. Avissar, and R. Nathan, "Compensation for lateral drift due to crosswind in migrating European Bee-eaters," Journal of Ornithology, vol. 155, no. 3, pp. 745-753, 2014.

[42] I. Smalley, K. O'Hara-Dhand, S. McLaren, Z. Svircev, and H. Nugent, "Loess and bee-eaters I: Ground properties affecting the nesting of European bee-eaters (Merops apiaster L.1758) in loess deposits," Quaternary International, vol. 296, pp. 220-226, 2013.

[43] F. Valera, R. Martín-Hernández, and M. Higes, "Evaluation of large-scale dissemination of Nosema ceranae spores by European bee-eaters Merops apiaster," Environmental Microbiology Reports, vol. 3, no. 1, pp. 47-53, 2011.

[44] B. Desalegn, "Some major pests and predators of honeybees in Ethiopia," in Proceedings of the 3rd National Annual Conference of Ethiopian Beekeepers Association, pp. 59-67, 2001.

[45] W. Loucif-Ayad, A. Chefrour, M. Algharibeh, and N. Haddad, "First detection of Deformed wing virus of honeybees in Algeria," Phytoparasitica, vol. 41, no. 4, pp. 445-447, 2013.

[46] C. T. Mumbi, A. R. Mwakatobe, I. H. Mpinga, A. Richard, and R. Machumu, "Parasitic mite, varroa species (parasitiformes: varroidae) infesting the colonies of african honeybees, apis mellifera scutellata (hymenoptera: apididae) in tanzania," Journal of Entomology and Zoology Studies, vol. 2, no. 3, pp. 188-196, 2014.

[47] K. Albala, The SAGE encyclopedia of food issues, SAGE Publications, Los Angeles, CA, USA, 2015.

[48] M. Suresh Kumar, A. J. A. Ranjit Singh, and G. Alagumuthu, "Traditional beekeeping of stingless bee (trigona sp) by kani tribes of western ghats, tamil nadu, india," Indian Journal of Traditional Knowledge, vol. 11, no. 2, pp. 342-345, 2012.

[49] S. Vojvodic, J. J. Boomsma, J. Eilenberg, and A. B. Jensen, "Virulence of mixed fungal infections in honey bee brood," Frontiers in Zoology, vol. 9, 2012.

[50] S. E. Evison, "Chalkbrood: Epidemiological perspectives from the host-parasite relationship," Current Opinion in Insect Science, vol. 10, pp. 65-70, 2015.

[51] S. A. Maxfield-Taylor, A. B. Mujic, and S. Rao, "First detection of the larval chalkbrood disease pathogen Ascosphaera apis (Ascomycota: Eurotiomycetes: Ascosphaerales) in adult bumble bees," PLoS ONE, vol. 10, no. 4, 2015. 


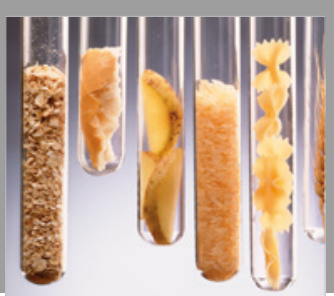

International Journal of Food Science

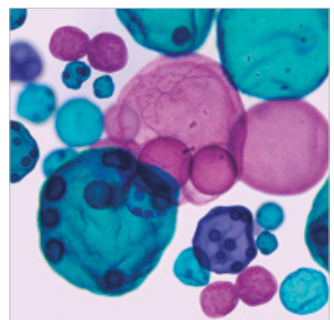

International Journal of Microbiology
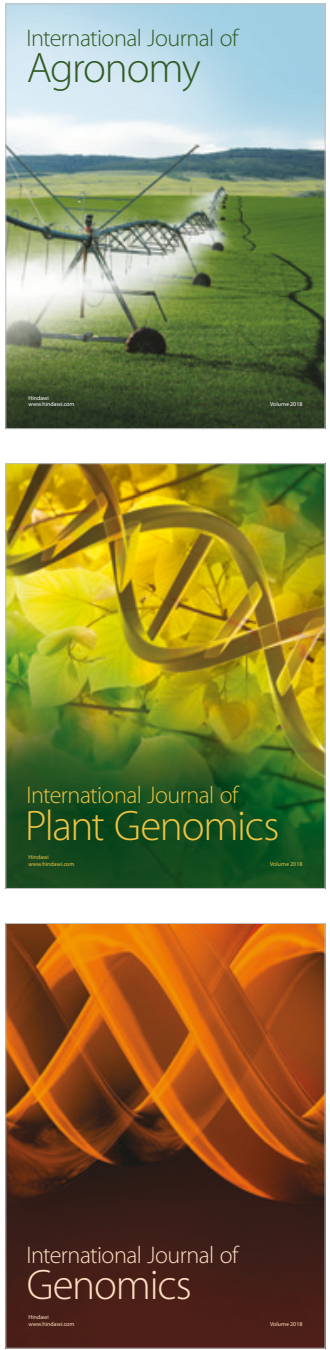

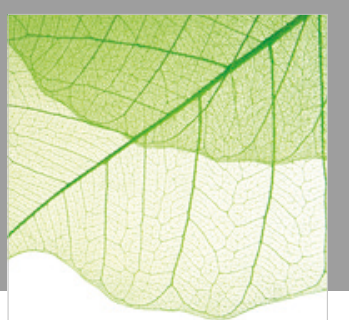

Journal of Botany
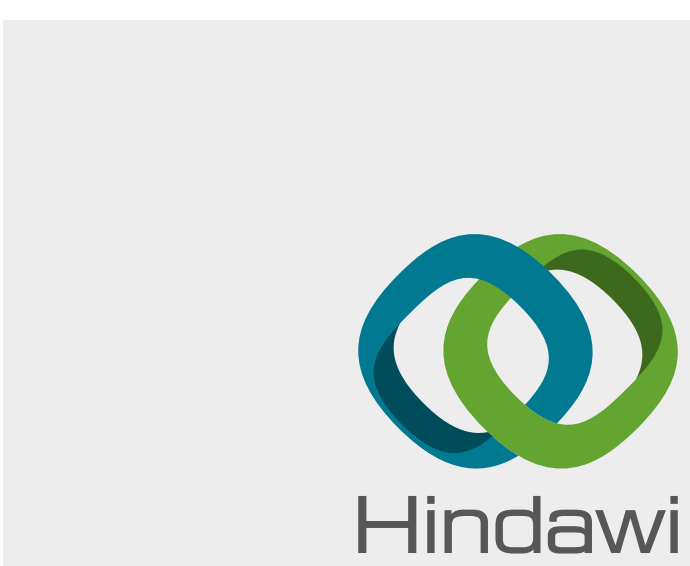

Submit your manuscripts at

www.hindawi.com
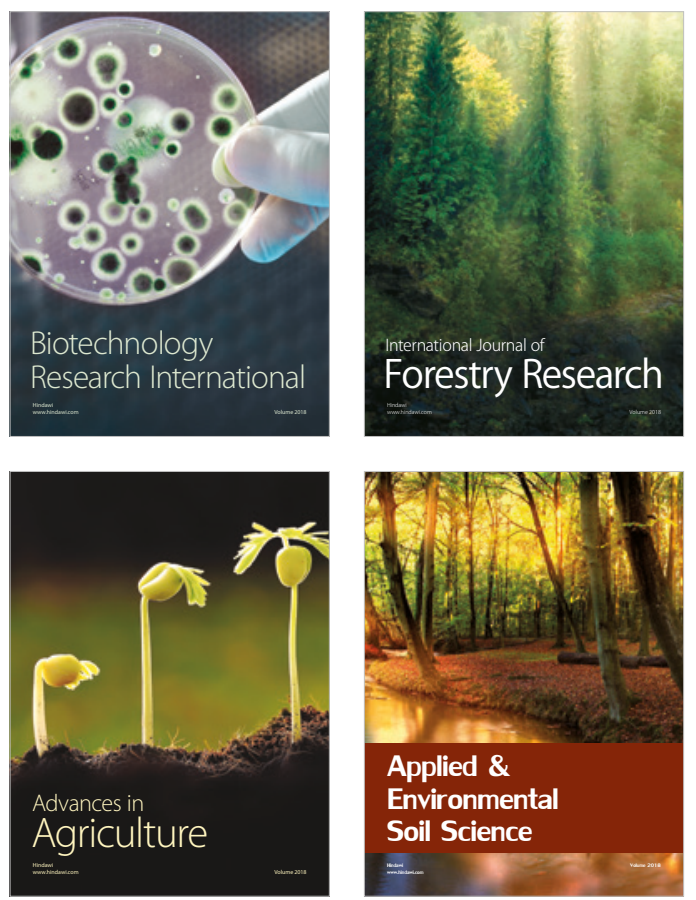

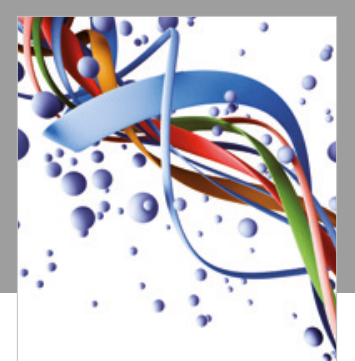

Scientifica

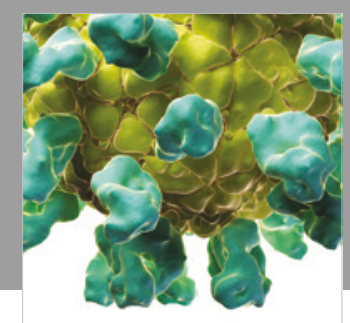

Veterinary Medicine International

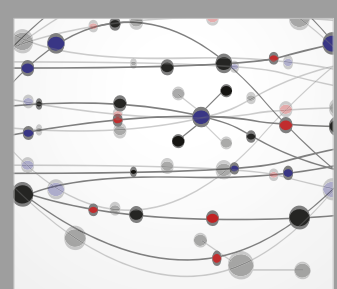

The Scientific World Journal
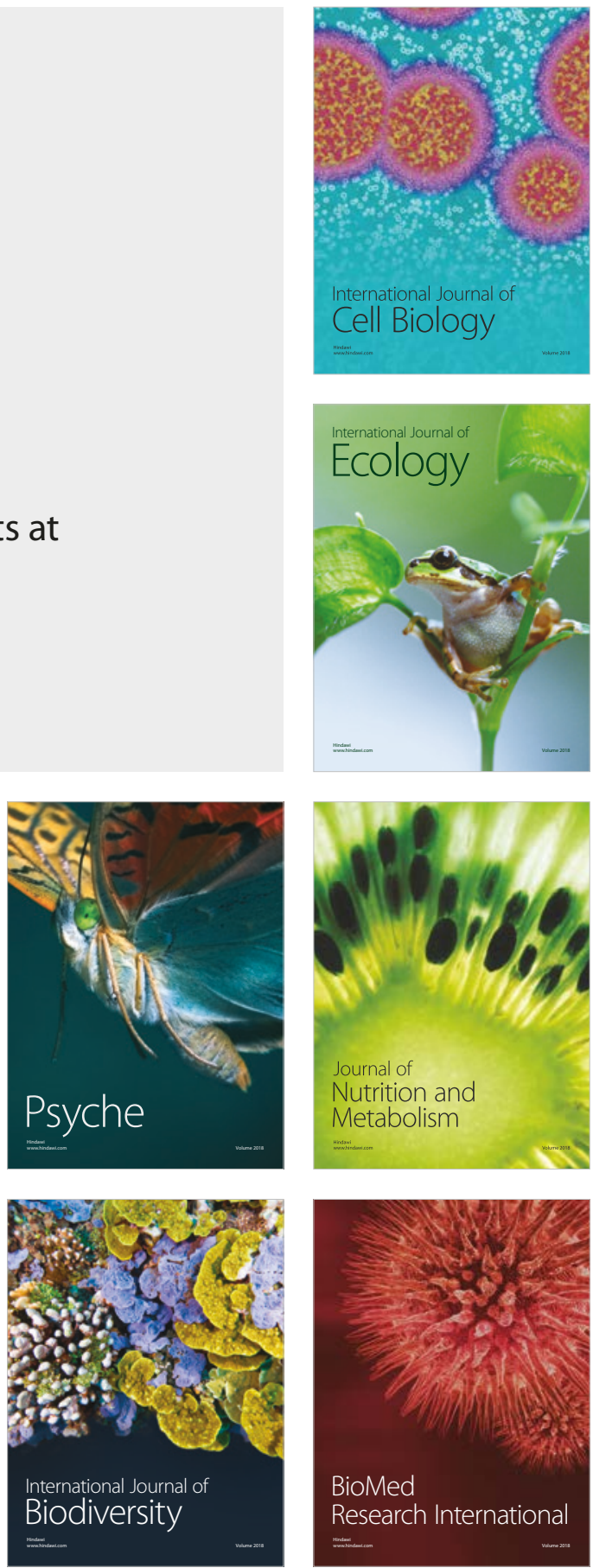